Klimczak M., First modern institutions of competition regulation - law and economics or law versus economics?, „Ekonomia i Prawo. Economics and Law.”, Polszakiewicz B., Boehlke J. (ed.), Vol. 13, No. 3/2014, pp. 431-448. DOI: http://dx.doi.org/10.12775/EiP.2014.031.

\title{
FIRST MODERN INSTITUTIONS OF COMPETITION REGULATION - LAW AND ECONOMICS OR LAW VERSUS ECONOMICS?
}

\author{
SUMMARY
}

Competition regulation nowadays is a result of a nexus of many intertwined phenomena, which under different circumstances might bring different results. Throughout the history of this process it is easy to observe quite complicated relationship between economic theories of competition and theory and practice of law. It might look, as if institutions regulating competition are simple realisation of economic theories. The truth is different, as competition regulation originated in times, when complex theoretical analysis of that type was not condemning trusts and was generally leaning towards self-regulatory powers of competition. The main theme of this paper is an attempt to identify the way of introducing the first modern competition regulation law. In the conclusion, the paper substantiates the hypothesis, that the economics played insignificant role in the whole process, it even might be stated, that the Sherman Antitrust Act was introduced despite the economists' scepticism towards such way of regulation of markets. In the analysis other explanations for the Act emerge: one rooted in public choice theory, the other taking into consideration motives of possible personal revenge of Sen. Sherman.

Keywords: regulation; antitrust; public policy, competition, Sherman Antitrust Act, Clayton Act

JEL Classification: D02, D60, L4

* Mikołaj Klimczak, Wrocław University of Economics, Faculty of Economics, Department of Economics and Institutional Economics, ul. Komandorska 118/120, 53-345 Wrocław, phone: +487136801 96, e-mail: mikolaj.klimczak@ue.wroc.pl. 


\section{INTRODUCTION}

Current shape of competition regulation is a result of evolution both economic, social and legal structures as well as certain systems of values influenced by ideas and beliefs. The evolution of instituitions regulating competition was not simple, due to the fact, that such policy was not something that evolved naturally, rather it was designed artificially supposedly to correct market failure. Competition regulation nowadays is a result of a nexus of many intertwined phenomena, which under different circumstances might bring different results.

Throughout the history of competition regulation it is easy to observe quite complicated relationship between economic theories of competition and theory and practice of law. It is specifically visible in the area of impact analysis and evaluation of dominant practices and mergers. Connection between law and economics is not as clear as it looks like while reading economic textbooks on topic of competition regulation. Students beginning such studies might arrive at the conclusion that current shape of the law of competition regulation is a clear realisation of claims included in economic theories, especially those analysing general welfare. It might look like this, until one studies the topic further and looks at the connections between law and economics chronologically. It becomes evident, that the sequence of events was different: fully fledged theories explaining the competition regulation (that is the theory of perfect competition and welfare economics among others) were developed significantly later than corresponding legal acts. Regardless of the method of calculation the difference might be between 30 and 50 years. This leads us to some significant questions about the origins of such formal institutions, introduced with the lack of relevant economic theories and discontent of the most of economists.

The main goal of this paper is an attempt to identify the way of introducing the first modern acts regulating competition, namely the Sherman Act (and to the smaller extent the Clayton Act) in the United States. Such analysis will allow to justify to what extent economic theories influenced the shape of these acts, that later served as a benchmark for other countries of the world. The analysis will be based upon the studies of primary and secondary documents on competition regulation, as well as case studies from the turn of the XX century. 


\section{COMPETITION REGULATION LAW}

Much was written about one of the first modern competition regulation law, that was adopted in the United States ${ }^{1}$. It took form of two acts: Sherman Antitrust Act of 1890 and Clayton Act of 1914, accompanied by rulings of courts that created the whole legal environment of institutions regulating competition. For the sake of better introduction to the problem, major points of both acts will be presented below.

\subsection{SHERMAN ANTITRUST ACT}

For the purpose of the general description Sections 1 and 2 are important and relevant. The former prohibits contracts, combinations and conspiracies that restraint the trade between the states and imposes fines and imprisonment for its violators. The latter prohibits monopolisation, attempts to monopolise and conspiracies to monopolise. Both Sections refer to the infringements in the scope of inter-state trade, as well as foreign trade (specifically imports) $)^{2}$.

During the first decade of the implementation of Sherman Act one can find many significant cases, that shaped the competition regulation in the future: Addyston Pipe \& Steel Co. v. United States ${ }^{3}$, Dr. Miles Medical Co. v. John D. Park and Sons ${ }^{4}$, Standard Oil Co. of New Jersey v. United States 5 , to name only the few. Their impact was far reaching and some of them remain in force even now.

\subsection{CLAYTON ACT}

Even though the Sherman Antitrust Act covers a wide range of cases, from market sharing and price fixing combinations to monopolization practices of a single company, it does not cover mergers. This enabled companies to merge instead of collude and fall out of the scope of the Act. The Clayton Act addressed this issue and prohibited mergers which reduced competition. It also explicitly forbids other practices, such as price discrimination, as

${ }^{1}$ Canada introduced similar law year earlier, but its enforcement proved to be much weaker. (M. Motta, Competition Policy, Cambridge University Press, Cambridge, New York, 2004, p. 3).

2 Sherman Act, 15 USC $\S$ 1-7, 1890.

3 Addyston Pipe E Steel Co. v. United States, 175 U.S. 211, 1899.

${ }^{4}$ Dr. Miles Medical Co. v. John D. Park and Sons, 220 U.S. 37, 1911.

5 Standard Oil Co. of New Jersey v. United States, 221 U.S. 1, 1911. 
well as introduced the possibility of private antitrust suits ${ }^{6}$. The Clayton Act was accompanied by the Federal Trade Commission Act, which introduced a new, independent agency that has responsibility to enforce competition regulation on the federal level ${ }^{7}$.

\section{GENERAL JUSTIFICATION FOR COMPETITION REGULATION}

Behind any country's competition regulation lies a simple declaration: this legal framework is designed in order to promote competition and through this economic efficiency. It has been acknowledged that some actions of companies might lead to ineffective allocation of resources. At the first glance, such order was replicated in the first acts protecting competition in the US, however some aspects of these regulations were inspired by different premises. Among others, politically conditioned protection of small and medium enterprises, promoted by the US Congress, can be named ${ }^{8}$.

After years of implementation, amendments and enforcement it is possible to compare competition regulation in the US to other countries. For various reasons, competition laws all over the world resembles institutions introduced in the US, however in the European Union competition law is based on slightly different premise: protection of competitors instead of protection of competition 9 . The enforcement is also different: in the EU it relies heavily on administrative decisions and bureaucratic structures, whereas in the US it is mainly judicial in its form ${ }^{10}$. Such difference in the enforcement brings different rulings in the same or similar cases - one of the most prominent examples being a series of Microsoft antitrust persecutions ${ }^{11}$.

Many economists, specifically those connected with Chicago school of economics point out, that economic efficiency should be perceived as the main goal of the competition regulation rather than protection of competi-

${ }^{6}$ Clayton Act, 15 USC $\S$ 12-27, 29 USC $\S 52-53,1914$.

7 Federal Trade Commission Act, 15 USC §§ 41-58, 1914.

${ }^{8}$ W.K. Viscusi, Economics of Regulation and Antitrust, MIT Press, Cambridge, 2005, p. 7071.

9 H. Disney, A More Subtle Anti-trust Regime for Europe, „Financial Times”, 2004.

${ }^{10}$ L. Bumgardner, Antitrust Law in the European Union, "Graziadio Business Review”, Vol. 8, No. 3/2005.

${ }^{11}$ For more detailed description of cases and reasons behind the EU and the U.S. rulings see: J.P. Jennings, Comparing The US And EU Microsoft Antitrust Prosecutions: How Level Is the Playing Field?, „Erasmus Law and Economics Review”, Vol. 2, No. 1/2006. 
tors $^{12}$. Whatever is the justification, when current competition regulation institutions are looked upon, it seems they are justified by economic theories and reflect fully their findings. The truth might be however far more complicated. To unravel this mystery, it is best to begin at the point of origin of modern institutions regulating competition: the Sherman Antitrust Act.

\section{DISCUSSION IN THE US SENATE BEFORE THE INTRODUCTION OF THE SHERMAN ANTITRUST ACT}

The discussion in the $51^{\text {st }}$ Senate took in total only seven days between $27^{\text {th }}$ of February and $8^{\text {th }}$ of April 1890. As compared with other discussions of different acts of the time it was significantly shorter ${ }^{13}$. However short, discussion of the proposed Antitrust Act shows different standpoints of Senators, and despite general acceptance of the Act, it can be seen, that not everyone was fully convinced and some were aware of different ways to deal with restraints of trade and commerce as well as monopolies. In the Senate, the Act was passed by the vote of 51-1 and in the House of Representatives unanimously $242-0^{14}$, which shows, that either all possible problems had been overcome in discussion or there had been other interests at stake that forced Senators to vote in favour of the Sherman Antitrust Act. It is also particularly interesting in the light of major differences between Democrats and Republicans in their views on economy - apparently in this matter there were no differences between the parties, which sounds rather unlikely and will be discussed later in the paper.

The discussion itself was quite interesting, introducing many peculiar points of view and showing how deeply ideological were the arguments. It also shows a certain disregard of Senators of economics and tendency towards simplifications.

Generally speaking the arguments in the discussion might be presented in two groups: these in favour of the Act and the ones against it.

The first group might be opened by the crown argument of supporters of the Act, that some trust prevent free and full competition among in-

12 R.H. Bork, The Antitrust Paradox: A Policy At War With Itself, Free Press, New York, 1993, p. 89.

13 S. Martin, Industrial Organization in Context, Oxford University Press, Oxford 2007, p. 610 .

14 OurDocuments.gov, Sherman Anti-Trust Act (1890), http://www.ourdocuments.gov/doc. php?flash=true\&doc=51 (14.10.2013). 
ternal and imported products. From this point of view, the Act should enable to maintain freedom of trade and production by controlling, restraining or prohibiting all combinations between individuals or corporations created to achieve such goal ${ }^{15}$. Sherman himself described the Act as a "bill of rights, a charter of liberty"16. In-depth analysis reveals at least two interesting points in such argument. Firstly, Senators, being non-economists, never defined some basic ideas used in either the discussion or the Act itself, to name competition as the major one. Throughout the discussion competition meant different things ranging from the market structure to the competitors themselves. Secondly, such an argument employs "big gun" of American democracy, namely the value of freedom that would be bestowed upon society as a result of the Act. Thanks to such phrasing any attempt to contradict the Act might be seen as the attempt on the fundamentals of the US.

Another argument in favour of the antitrust regulation was expressed by Senator Turpie, who said that all trusts sell or produce goods in a way, that "common stock is made with the intention of holding and selling the same at an enhanced price, by suppressing or limiting the supply and by other devices, so that the price of such trust commodity shall depend merely upon the agreement made about it by those in combination, without reference to the cost of its production, the quantity of the article held for consumption, or the demand therefor among buyers" ${ }^{17}$. As can be clearly seen, this Democrat Senator at first shows knowledge of microeconomics, that enables him to draw conclusion about the result of decreased supply - a phenomenon, that in his opinion is a goal of trusts. Later however his argument falls prey to simplification and steers away from what we now understand as the supply and demand equilibrium analysis. However, this argument was by far the most advanced economically among those in favour - especially from the point of view, that Marshall's "Principles of Economics" were not yet published (they were published later in 1890 - the Preface to the first edition is dated on September 1890) ${ }^{18}$ and the earlier work of Jenkin from 1870, that introduced supply and demand analysis and comparative statics, was not so widely known ${ }^{19}$. However sound the argument of Sen. Turpie is, his justification is based on the premise, that trusts aim only at price increase, which is

15 J. Sherman, Senate Discussion, „Congressional Record”, Vol. 21/1890, p. 2457.

${ }^{16}$ Ibidem, p. 2461.

17 D. Turpie, Senate Discussion, „Congressional Record”, Vol. 21/1890, p. 138.

18 A. Marshall, Principles of Economics, Library of Economics and Liberty, London 1920.

19 A.D. Brownlie, M.F.L. Prichard, Professor Fleeming Jenkin, 1833-1885 Pioneer in Engineering and Political Economy, „Oxford Economic Papers”, Vol. 15, No. 3/1963, p. 204-216. 
not true in the long run analysis, as trusts had a multitude of reasons, such as assurance of supply of factors of production and many others. This particular problem was addressed by Sen. Sherman, who acknowledged another goal of trusts but profit maximisation. He observed, that trusts also can aim at efficiency of production and purchases of factors of production (e.g. through combined orders), however he said that "all experience shows that this saving of cost goes to the pockets of the producer"20. From this statement, we might perceive, that Sen. Sherman was concerned about the influence of market power on income distribution.

Senator Sherman expressed also another concern - in his view, trusts aim at eradication of competition, and they do it using a specific strategy, that nowadays is called elimination strategy or predatory pricing. He said, that trusts aim at realisation of their selfish interests and "reduce prices in a particular locality and break down competition and advance prices at will where competition does not exist (...) [its] governing motive is to increase the profits of the parties composing it"21. Taking neoclassical approach to the problem it is hard to find anything particularly alarming in the scenario of Sen. Sherman, unless we employ welfare economics and long term analysis - neoclassical economics assumes, that companies in short run do maximise profits, homo oeconomicus is somewhat selfish in the pursuit of his private interest and oligopolists use price competition, especially in the markets where heterogeneity is low. We now are aware, that such actions cause an increase in market power and build up barriers to entry, which might have adverse effects on market performance and welfare - but such analysis was not available at the end of the XIX century.

One of the most important arguments raised by Senators was concern, that the Act could penalise a company, which gained monopoly through its merits or pure coincidence - without any effort. Senator Kenna expressed such concern ${ }^{22}$, and was assured by Senator Edmunds, that it will not be a case, because the Act aims only at the companies that dominate markets through misconduct. The discussion between these two Senators is not satisfying, because Sen. Kenna expressed an important problem with the Act and Sen. Edmunds replied with nothing but assurances, that such thing would not happen. He also said, that a person, who would become the only producer or trader in some market cannot be called monopolist. This proves difficult to understand, but the definition of a monopoly perceived at the time was slight-

\footnotetext{
${ }^{20}$ J. Sherman, op. cit., p. 2460.

${ }^{21}$ Ibidem, p. 2457.

22 J.E. Kenna, Senate Discussion, „Congressional Record”, Vol. 21/1890, p. 3151.
} 
ly different from current one. In view of Senators it was a technical term that included misconduct and prevention of competition on the market. The problem lies therefore in definition, which by proponents of the Act was rather legal and by opponents leaning towards modern economic one.

The main problem with the common law and acts such as Sherman Antitrust Act lies therefore in their vagueness - it is the courts that will interpret the Act. Sherman even said: "I admit, that it is difficult to define in legal language the precise line between lawful and unlawful combinations. This must be left for the courts to determine in each particular case. All that we, as lawmakers, can do is to declare general principles, and we can be assured that the courts will apply them so as to carry out the meaning of the law, as the courts of England and the United States have done for centuries"23.

This point of view, combined with the previous inability to define basic ideas that the Act referred to, produced more than 120 years of history of American antitrust that is full of turning points, decisions of courts that turned the competition regulation upside down several times in many areas. Declaration of general principles and articulation of the meaning of the law on behalf of the $51^{\text {st }}$ Senate that introduced the Sherman Antitrust Act was apparently not complete.

One of the most important arguments for the introduction of the Sherman Antitrust Act, was that it would strengthen common law and reaffirm it expressly in the US. If it really was the case, the Act would just put in a single document the law that was already working. The Act therefore could be redundant and it raised some serious concerns ${ }^{24}$. The answer for this in the discussion was that the Act would extend the common law to interstate and international commerce in the US. This seems to be quite reasonable justification, however it leaves the question what exactly would be that common law that was extended on a federal level? The short answer for this question will be provided in the next point of the paper.

Beside such obvious arguments Senators also brought several others:

- the Act would empower private parties to pursue their rights against trusts ${ }^{25}$,

- the Act would protect small business, that lay in ruin as a result of actions of a few enabled by the government ${ }^{26}$,

23 J. Sherman, op. cit., p. 2459.

${ }^{24}$ J.E. Kenna, op. cit., p. 3151.

25 J. Sherman, op. cit., p. 2569.

${ }^{26}$ J.Z. George, Senate Discussion, „Congressional Record”, Vol. 21/1890, p. 2598. 
- actions of trust are against democracy, because it enables to gather "royal" power in their hands 27.

The second group of arguments - the ones against the Sherman Antitrust Act - is opened by an argument of Senator Vest. It can be successfully maintained that his statement against the Sherman Antitrust Act was the best one. He said "If the high protective tariff were removed the foreign competition would furnish, if not an absolute, certainly a most beneficial remedy to remove this evil" 28 pointing out the situation of the time, when the US was protected from foreign competition by tariffs. This argument is a very conscious one, because it refers to bringing down barriers to entry on American markets, which should increase the competition. However sound, this argument was dismissed and left no particular mark in the discussion. This argument is also particularly interesting in the light of the events that occurred in the second half of 1890, which will be discussed later in this paper.

There were also some other minor arguments against the Act:

- the Act would also apply to organised labour and small business ${ }^{29}$; Sherman himself stated, that the Act would not apply to labour unions, which proved later not to be true.

- Senator Stewart claimed that combination of people is inevitable as an innate process that distinguish "civilised men" from savages ${ }^{30}$.

For the people of our time, armed with the knowledge of economics, such discussion might seem rudimentary and unprofessional. It has to be however stressed, that at least some Senators proved to be conscious of economy and sharp in their conclusions - and this applies mainly to Senators voicing their concerns with the proposed Antitrust Act.

\section{DECLARED JUSTIFICATION FOR THE SHERMAN ANTITRUST ACT}

Based on this discussion presented above it is easy to formulate general declared or "meant" justification for the Sherman Antitrust Act. First and foremost point refers to the argument, that the Sherman Antitrust Act codified only common law of England and United States. As stated above, this argument is a sound one, unless this set of common law is closely scrutinised. When analysed it occurs, that the common law, to which Senators in the dis-

\footnotetext{
27 J. Sherman, op. cit., p. 2457.

28 G.G. Vest, Senate Discussion, „Congressional Record”, Vol. 21/1890, p. 2466-2467.

${ }_{29}$ W.M. Stewart, Senate Discussion, „Congressional Record”, Vol. 21/1890, p. 2565.

${ }^{30}$ Ibidem, p. 2564.
} 
cussion referred to, is a carefully selected set, practically designed to prove the point. Cases come from court decisions of different jurisdictions and reflect fairly loose mixture of outlooks on economy of Senators supporting the $\mathrm{Act}^{31}$.

In the discussion Sen. Sherman demonstrated only superficial economic knowledge, that relied on the premise that higher prices are generated by the decrease of supply. He said: "can it [Senate] not protect commerce, nullify contracts that restrain commerce, turn it from its natural courses, increase the price of articles, and therefore diminish the amount of commerce?" 32 . This was the second of important arguments for implementation of the Act.

Generally, despite the fact that the language of the Act does not include the word competition (which is peculiar in itself and raises some questions) thanks to the records of discussion we might state that its aim was to promote competition understood as independent decision making of all undertakings. Common hostility of society in general and of Congress in particular towards trusts and monopolies might had its roots in conviction that they are harmful from the point of view of buyers' interests, damaging to the small business and conflicting with the democratic institutions ${ }^{33}$.

In the whole process of introducing the Antitrust Act no experts were officially consulted. Actually it was the common feature of legislative process of the time, not to consult anyone, as Senators were commonly perceived as omniscient representatives of the people. They instead managed to quote some of the old classics, who mentioned monopolies or cartel in a very vague manner (as Adam Smith did) ${ }^{34}$.

\section{REACTIONS TO COMPETITION PROCTECTION IN THE US BEFORE AND AFTER THE SHERMAN ANTITRUSTACT}

The Sherman Antitrust Act enjoyed widespread support of many intellectualists from many fields - practically all except of economics ${ }^{35}$. Cold approach of economists towards the Act is peculiar from the point of view of earlier analysis. Shouldn't it be that economists supported the introduction of the Antitrust Act in the first place? Why economists were quite unwel-

${ }^{31}$ R.H. Bork, op. cit., p. 20.

32 J. Sherman, op. cit., p. 2462.

${ }^{33}$ H.B. Thorelli, The Federal Antitrust Policy: Origination of an American Tradition, Johns Hopkins Press, Baltimore 1955, p. 227.

34 Ibidem, p. 567.

35 T.J. DiLorenzo, J.C. High, Antitrust and Competition, Historically Considered, „Economic Inquiry", Vol. 26, No. 3/1988, p. 423. 
come of the new law that institutionalised the competition regulation? After Stigler, several explanations can be given:

- economists did not perceive the importance and negative effects of combinations, especially those of hidden nature,

- economists overestimated other types of "controlling economic activity alternative to the market are public regulation and ownership",

- economists underestimated antitrust as an important part of their work and income ${ }^{36}$.

Even though plausible, such explanations are not satisfactory, even to their author himself. They also seem a little biased, specifically the first one, which assumes general premise that all combinations are harmful and does not allow more basic discussion about the negative and positive effects of trusts or simply market and government failure duality of economy.

This widespread disapproval of economists calls certainly for better explanation, who exactly was not fond of competition regulation in the form introduced in the United States. Generally speaking before 1890 two different outlooks on competition and rivalry were observable amongst economists. The first one can be summarized with the statement that competition is not effective enough to secure resource allocation, especially in a situation, where high fixed and sunk costs are required. It this situation some degree of public control is indispensable, but not high and certainly not only regulating competition. J.B. Clark was the economist generally associated with this point of view ${ }^{37}$ and beside him, similar themes were also explored by Davenport ${ }^{38}$, Ely $^{39}$, Laughlin ${ }^{40}$, Seligman $^{41}$, Fisher $^{42}$ and many others. The second one, represented by e.g. Gunton, stated that the threat of potential competition is restricting enough to limit the use of market power ${ }^{43}$. Similarly, about potential

${ }^{36}$ G.J. Stigler, The Economists and the Problem of Monopoly, "The American Economic Review", Vol. 72, No. 2/1982, p. 5-6.

37 J.B. Clark, The Limits of Competition, „Political Science Quarterly”, Vol. 2, No. 1/1887, p. $45-61$.

${ }^{38}$ H.J. Davenport, The Economics of Enterprise, The Macmillan Co., New York 1919.

39 R.T. Ely, Monopolies and Trusts, Citizen's Library of Economics, Politics, and Sociology, The Macmillan Company, London 1900.

${ }^{40}$ J.L. Laughlin, The Elements of Political Economy, American Books Co., New York 1902.

${ }^{41}$ E.R.A. Seligman, Principles of Economics, Longmans, Green and Co., New York 1909.

${ }^{42}$ I. Fisher, Elementary Principles of Economics, The Macmillan Company, New York 1916.

${ }^{43}$ G. Gunton, The Economic and Social Aspect of Trusts, „Political Science Quarterly”, Vol. 3, No. 3/1888, p. 385-408. 
competition as a detriment to competition, Marshall ${ }^{44}$, Laughlin ${ }^{45}$, Taussig ${ }^{46}$, Seligman ${ }^{47}$ or Hadley ${ }^{48}$ were writing. It has to be noted, that the third possibility is not mentioned here, which is the opinion that the introduction of the Antitrust Act was a justified move. There were virtually no economists before 1920 who endorsed competition regulation in the form introduced in the US.

Why economists perceived negatively the formal institutionalization of competition regulation? To answer this question it is crucial to take a closer look at the economy of the end of XIX century.

\section{ECONOMY AT THE TURN OF THE XX CENTURY: LAW AGAINST ECONOMICS?}

To present the background of the first modern institutions of competition regulation it will be interesting to begin with a short description of the situation in other countries, especially in Europe. The economy in European countries was open one and based upon the premise of inter-country competition. It means that at least in some situations geographically relevant markets were larger than countries. Throughout the XIX century, which in Europe was relatively peaceful and free of major military conflicts, the manufacturing industry had a chance for development. Countries traded with each other and had been competing on the international level ${ }^{49}$. In XIX century England the majority of enterprises were still run by families, which functioned differently from the American corporations. English, as well as French or German economy was established on premises that had its roots deep in lasseiz-faire movement. In Germany, country which was undergoing integration processes, cartels were a natural way of organization of economic activity.

Whereas, the United States after decimating civil war underwent the change in ownership conditions. Additionally, in order to protect internal pro-

${ }^{44}$ A. Marshall, Industry and Trade. A Study of Industrial Technique and Business Organization, Macmillan and Co. Limited, London 1919.

45 J.L. Laughlin, op. cit.

${ }^{46}$ F.W. Taussig, Principles of Economics, Vol. 2, Cosimo Classics, New York 2013.

47 E.R.A. Seligman, op. cit.

48 A.T. Hadley, Economics: An Account of the Relations Between Private Property and Public Welfare, G.P. Putnam's Sons, London 1896.

${ }^{49}$ L. McGowan, The Antitrust Revolution in Europe: Exploring the European Commission's Cartel Policy, Edward Elgar Publishing, Northampton 2010, p. 44; for the discussion about this see: G.J. Stigler, The Origin of the Sherman Act, „The Journal of Legal Studies”, Vol. 14, No. 1/1985, p. 1-12. 
duction and promote growth, high tariffs were introduced, which closed the US for the competitors from abroad ${ }^{50}$. Interesting is the fact, that the same $51^{\text {st }}$ Congress, in the same 1890 but three months later, introduced a new tariff act, which had quite protectionist goal. Such duality of views is remarkable: at first the introduction of the Antitrust Act, which clearly had a goal of protecting consumers against increases in prices, after this the introduction of new tariff law that had adverse effect of the protection of producers at the expense of consumers. It cannot be attributed to the ignorance of the Congress, as the Sherman Antitrust Act introduced several exemptions - among others for the export cartels, which showed that Congressmen knew about the international scope of competition.

The economic literature in majority includes justification for the Sherman Antitrust Act that was typical and contains the information about the widespread public support for it. It is interesting to observe what was happening in American economy at the time. For example prices of kerosene were falling combined with the increase in sales. Americans benefited also from standardisation and the increase in quality, which accompanied the increase of market shares of Standard Oil ${ }^{51}$. Moreover, the practices of train networks stabilised and increased incomes of farmers, as was reported by Stigler ${ }^{52}$.

As was mentioned above, the Congress did not conduct any analyses, while discussing the Antitrust Act. It is peculiar, because economists of the time had been already mentioning the possibility of positive effects of the scale of production and competition was treated as a process, rather than structure $^{53}$.

How was this connected with the tariff act? Sherman was personally interested, as a republican Senator, in maintaining high tariffs, similarly as every Democrat was interested in abolishing them. This Act, later dubbed the McKinley Tariff was also called "Campaign Contributors' Tariff Bill” brought a great shock in the US. The New York Times wrote that: "so-called AntiTrust law was passed to deceive the people and to clear the way for the enactment of this Pro-Trust law relating to the tariff. It was a humbug and a sham.

50 D.A. Irwin, Did Late-Nineteenth-Century U.S. Tariffs Promote Infant Industries? Evidence from the Tinplate Industry, „The Journal of Economic History”, Vol. 60, No. 2/2000, p. 335360; T. Cowen, Did Tariffs Boost 19th Century U.S. Economic Growth?, 2006, http://marginalrevolution.com/marginalrevolution/2006/07/did_tariffs_boo.html (19.10.2013); D.A. Irwin, Tariffs and Growth in Late Nineteenth Century America, NBER Working Papers, No. 7639/2000.

51 R.L. Bradley Jr., On the Origins of the Sherman Antitrust Act, „The Cato Journal”, Vol. 9, No. 3/1990, p. 739.

52 G.J. Stigler, The Origin..., op. cit., p. 3.

53 T.J. DiLorenzo, J.C. High, op. cit. 
It was projected in order that the party organs might say to the opponents of tariff extortion and protected combinations, „Behold! We have attacked the Trusts. The Republican Party is the enemy of all such rings»" ${ }^{54}$.

Why Sherman was waiting until 1888 to start the legislative process for the Antitrust Act in the situation, where potential problem was known from early 1870s? Why didn't he mentioned the simplest of solutions, which was the decrease of tariffs?

It is interesting to discover where was Sherman in 1888 in his political career. In that year he was trying to receive his party's nomination to become the candidate for the president of the United States. His candidacy was rejected in multi-staged voting and he was blaming his failure on his colleague, Russel A. Alger, whom he accused of vote trading ${ }^{55}$. Alger was, what is important, timber industry millionaire and a producer of matches. This last role was specifically interesting and important: Alger was a member of a trust called Diamond Match Company. This trust became one of the main examples of "bad trusts" provided by Sherman in discussions about the Act. President Harrison, when signing the Antitrust Act was supposed to say: "John Sherman has fixed General Alger" ${ }^{56}$. Many scientists opine, that the revenge might not be the driving force for Sherman, it was rather the need to leave something behind, when he failed to run for president. Although this story might be apocryphal, the connection between Sherman and Alger and the sequence of events is indeed striking.

The aftermath of Sherman Antitrust Act was multifaceted. One of the consequences of it was the quest of corporations to find a way to evade the Act and they found it easily. Instead of collusion in form of trust or any other combination, companies started to merge, forming new, larger corporations. After 1890 in the US, a grate wave of mergers might be observed. Such tendency forced the introduction of Clayton Act, which, for better or worse, also addressed this as well as other issues of the enforcement of antitrust ${ }^{57}$.

${ }^{54}$ The New York Times, Mr. Sherman's Hopes and Fears, http://query.nytimes.com/gst/abstract.html?res=9B06E4D7103BE533A25752C0A9669D94619ED7CF (19.10.2013).

55 The New York Times, Sherman to Alger, http://query.nytimes.com/gst/abstract.html?res=9 F04E0DA153BE533A25756C2A9659C94619ED7CF (19.10.2013).

${ }^{56}$ M. Gresham, Life of Walter Quintin Gresham 1832-1895, Rand, McNally, Chicago1919, p. 632 .

57 M. Motta, op. cit., p. 5. 


\section{CONCLUSIONS}

The way which the first antitrust regulation was introduced proved to be complex and complicated. As can be clearly seen from the analysis presented above, the economics played insignificant role in the whole process, it even might be stated, that the Sherman Antitrust Act was introduced despite the economists' scepticism towards such way of regulation of markets. Deeper analysis provides even more striking conclusions: the antitrust regulation might be a result of some power play in the Congress and public choice theory might be better suited for the analysis of this process than any other economic theory. What is more unusual, another explanation emerges, even though it is hard to believe in one: the Antitrust act might be a result, to certain extent, personal revenge of Sherman on a member of a trust. Neither of such conclusions might be easily dismissed, which gives a rise to some serious doubts about the origin and common justification for the Sherman Antitrust Act.

\section{BIBLIOGRAPHY}

Addyston Pipe \& Steel Co. v. United States, 175 U.S. 211, 1899.

Bork R.H., The Antitrust Paradox: A Policy At War With Itself, Free Press, New York, 1993.

Bradley Jr. R.L., On the Origins of the Sherman Antitrust Act, „The Cato Journal”, Vol. 9, No. 3/1990.

Brownlie A.D., Prichard M.F.L., Professor Fleeming Jenkin, 1833-1885 Pioneer in Engineering and Political Economy, „Oxford Economic Papers,” Vol. 15, No. 3/1963.

Bumgardner L., Antitrust Law in the European Union, "Graziadio Business Review”, Vol. 8, No. 3/2005.

Clark J.B., The Limits of Competition, „Political Science Quarterly”, Vol. 2, No. 1/1887, http://dx.doi.org/10.2307/2139316. Clayton Act, 15 USC §§ 12-27, 29 USC §§ 52-53, 1914.

Cowen T., Did Tariffs Boost 19th Century U.S. Economic Growth?, 2006, http://marginalrevolution.com/marginalrevolution/2006/07/did_tariffs_boo.html (19.10.2013).

Davenport H.J., The Economics of Enterprise, The Macmillan Co., New York 1919.

DiLorenzo T.J., High J.C., Antitrust and Competition, Historically Considered, „Eco-nomic Inquiry", Vol. 26, No. 3/1988, http://dx.doi.org/10.1111/j.1465-7295.1988. tb01505.x.Disney H., A More Subtle Anti-Trust Regime for Europe, „Financial Times", 2004.

Dr. Miles Medical Co. v. John D. Park and Sons, 220 U.S. 373, 1911. 
Ely R.T., Monopolies and Trusts, Citizen's Library of Economics, Politics, and Sociol-ogy, The Macmillan Company, London 1900.

Federal Trade Commission Act, 15 USC §§ 41-58, 1914.

Fisher I., Elementary Principles of Economics, The Macmillan Company, New York 1916.

George J.Z., Senate Discussion, „Congressional Record”, Vol. 21/1890.

Gresham M., Life of Walter Quintin Gresham 1832-1895, Rand, McNally, Chicago 1919.

Gunton G., The Economic and Social Aspect of Trusts, „Political Science Quarterly”, Vol. 3, No. 3/1888, http://dx.doi.org/10.2307/2139050.

Hadley A.T., Economics: An Account of the Relations Between Private Property and Public Welfare, G.P. Putnam's Sons, London 1896.

Irwin D.A., Did Late-Nineteenth-Century U.S. Tariffs Promote Infant Industries? Evi-dence from the Tinplate Industry, „The Journal of Economic History”, Vol. 60, No. 2/2000, http://dx.doi.org/10.1017/s0022050700025122.

Irwin D.A., Tariffs and Growth in Late Nineteenth Century America, NBER Working Papers, No. 7639/2000.

Jennings J.P., Comparing The US And EU Microsoft Antitrust Prosecutions: How Level Is the Playing Field?, „Erasmus Law and Economics Review”, Vol. 2, No. 1/2006.

Kenna J.E., Senate Discussion, „Congressional Record”, Vol. 21/1890.

Laughlin J.L., The Elements of Political Economy, American Books Co., New York 1902.

Marshall A., Industry and Trade. A Study of Industrial Technique and Business Organ-ization, Macmillan and Co. Limited, London 1919.

Marshall A., Principles of Economics, Library of Economics and Liberty, London 1920.

Martin S., Industrial Organization in Context, Oxford University Press, Oxford 2007.

McGowan L., The Antitrust Revolution in Europe: Exploring the European Commis-sion's Cartel Policy, Edward Elgar Publishing, Northampton 2010.

Motta M., Competition Policy, Cambridge University Press, Cambridge, New York, 2004.

OurDocuments.gov, Sherman Anti-Trust Act (1890), http://www.ourdocuments.gov/ doc.php?flash=true\&doc=51 (14.10.2013).

Seligman E.R.A., Principles of Economics, Longmans, Green and Co., New York 1909. Sherman Act, 15 USC $\S 1-7,1890$.

Sherman J., Senate Discussion, „Congressional Record”, Vol. 21/1890.

Standard Oil Co. of New Jersey v. United States, 221 U.S. 1, 1911.

Stewart W.M., Senate Discussion, „Congressional Record”, Vol. 21/1890.

Stigler G.J., The Economists and the Problem of Monopoly, „The American Economic Review", Vol. 72, No. 2/1982.

Stigler G.J., The Origin of the Sherman Act, „The Journal of Legal Studies”, Vol. 14, No. 1/1985, http://dx.doi.org/10.1086/467763.

Taussig F.W., Principles of Economics, Vol. 2, Cosimo Classics, New York 2013. 
The New York Times, Mr. Sherman's Hopes and Fears, http://query.nytimes.com/ gst/abstract.html?res=9B06E4D7103BE533A25752C0A9669D94619ED7CF (19.10.2013).

The New York Times, Sherman to Alger, http://query.nytimes.com/gst/abstract.html?re $\mathrm{s}=9 \mathrm{~F} 04 \mathrm{E} 0 \mathrm{DA} 153 \mathrm{BE} 533 \mathrm{~A} 25756 \mathrm{C} 2 \mathrm{~A} 9659 \mathrm{C} 94619 \mathrm{ED} 7 \mathrm{CF}$ (19.10.2013).

Thorelli H.B., The Federal Antitrust Policy: Origination of an American Tradition, Johns Hopkins Press, Baltimore 1955.

Turpie D., Senate Discussion, „Congressional Record”, Vol. 21/1890.

Vest G.G., Senate Discussion, „Congressional Record”, Vol. 21/1890.

Viscusi W.K., Economics of Regulation and Antitrust, MIT Press, Cambridge 2005. 
